\title{
Specimen-based databases of Australian plant pathogens: past, present and future
}

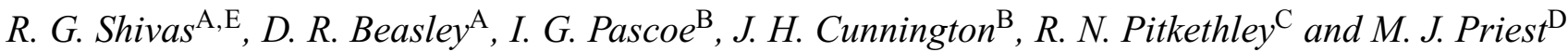 \\ APlant Science, Department of Primary Industries and Fisheries, 80 Meiers Road, Indooroopilly, Qld 4068, Australia. \\ ${ }^{B}$ Primary Industries Research Victoria, Department of Primary Industries, Private Bag 15, Ferntree Gully Delivery Centre, \\ Vic. 3156, Australia. \\ ${ }^{\mathrm{C}}$ Primary Industry, Department of Business, Industry and Resource Development, GPO Box 3000, \\ Darwin, NT 0801, Australia. \\ ${ }^{\mathrm{D}}$ Orange Agricultural Institute, NSW Department of Primary Industries, Forest Road, Orange, NSW 2800, Australia. \\ ${ }^{\mathrm{E}}$ Corresponding author. Email: roger.shivas@dpi.qld.gov.au
}

\begin{abstract}
Specimen-based records of most of the plant pathogens that occur in Australia can be accessed through the Australian Plant Disease Database and the Australian Plant Pest Database. These databases and the herbaria that underpin them are important resources for resolving quarantine and trade issues as well as for the diagnosis of plant diseases. The importance of these collections and databases to Australia's agricultural industries is discussed.
\end{abstract}

\section{Past}

Most of the specimens of plant pathogens currently preserved in Australian collections are held in the three herbaria located in State Departments of Agriculture or Primary Industries in Queensland (BRIP), New South Wales (DAR) and Victoria (VPRI) (May 1997). These three herbaria collectively constitute the National Collection of Fungi, a title conferred by the Standing Committee on Agriculture and Resource Management (SCARM) Plant Health Committee. The herbarium abbreviations BRIP, DAR and VPRI are listed in Index Herbariorum (Holmgren et al. 1990), which is a detailed directory of most of the world's herbaria. Historically, the abbreviations were chosen from $\boldsymbol{B}$ risbane $\boldsymbol{P}$ athogen, Department of $\boldsymbol{A}$ griculture $\boldsymbol{R y d a l m e r e ,}$ and $\boldsymbol{V}$ ictorian $\boldsymbol{P}$ lant $\boldsymbol{R}$ esearch Institute, which are now redundant names although the herbarium abbreviations are fixed and will remain unchanged.

May and Pascoe (1996) have given a comprehensive account of the history of taxonomic mycology in Australia, which includes information about collections and collectors of plant pathogens. The earliest collections of plant pathogenic fungi in Australia were often associated with, although not necessarily collected by, the botanists Ferdinand von Mueller (1825-1896) and Frederick M. Bailey (1827-1915), who sent the specimens to European mycologists for study. Bailey collected more than 1000 specimens of fungi including plant parasites. Bailey's collection was housed in the Queensland Herbarium (BRI) until 1968 when it was transferred to BRIP.
It was not until the appointment of Daniel McAlpine as Consulting Vegetable Pathologist in the Victorian Department of Agriculture in 1890 that the dedicated collection of plant pathogens in Australia began in earnest (May and Pascoe 1996). McAlpine established the first mycological herbarium in Australia, which at the time of his retirement in 1924 contained over 9000 specimens of which about 6000 were Australian and the remainder overseas exsiccatae that he had been sent. Most of this collection, which includes many of McAlpine's type specimens, is now housed in VPRI. In the same year as the appointment of McAlpine in Victoria, Nathan Cobb was appointed as a pathologist in New South Wales. Although Cobb was a prolific publisher on new diseases and produced a host index of Australian fungi, very few of his specimens have been preserved.

Two other important collections that have been absorbed by the National Collection of Fungi are BRIU and ADW. Raymond F.N. Langdon maintained an important collection (BRIU) of plant pathogens, particularly rusts, smuts and ergots, at The University of Queensland dating back to 1941. In 1970, the specimens in BRIU were transferred mostly to BRIP with some going to DAR. In 1999, DAR absorbed the microfungal collection from the Waite Institute in South Australia (ADW).

The Plant Pathology Herbarium (DAR) began databasing its collection in 1974 and continued until 1979, at which time nearly 30000 records had been captured. General databasing of the three major collections began in 1991 after 
the unanimous decision of the curators to use KE Titan (KE Software Pty Ltd), a post-relational information management system that was able to retrieve information at a speed not previously attainable. KE Texpress, a database management system that has a unique indexing mechanism that ensures exceptional retrieval speed, even for extremely large collections of data, superseded KE Titan. By the time of the launch of the Australian Plant Disease Database (APDD) in April 2002, the three herbaria were able to provide nearly all of their collection records electronically.

\section{Present}

As at January 2005, BRIP had 46000 specimens (including 41000 fungi), DAR had 108000 specimens (including 85000 fungi) and VPRI had 35000 specimens (including 28000 fungi). In addition, the three collections hold several thousand specimens of nematodes, bacteria and viruses.

The specimen collection records of the three herbaria (BRIP, DAR and VPRI) can be accessed through APDD, which was developed under a cost-sharing agreement between the State and Federal Governments. APDD is one of a growing number of biological portals that provides highly accurate information on the occurrence of plant diseases in Australia. It is a major tool for both State and Federal plant quarantine agencies. BRIP provides data to APDD via the database application KE EMu (KE Software Pty Ltd). DAR and VPRI provide data to APDD via the KE Texpress database system. The file server for APDD is maintained at the Victorian Department of Primary Industries, Knoxfield. The plant disease records of the Northern Territory will be added to APDD in the near future. These records are currently held in an Excel spreadsheet and will be transferred to APDD via KE EMu on a dedicated file server currently installed at Queensland Department of Primary Industries, Yeerongpilly.

$\mathrm{KE}$ EMu has several features that have proven to be invaluable for the development of a plant disease database. As well as a specimen catalogue (Fig. 1), this database also includes a suite of customisable modules (i.e. loans, parties, bibliography and multimedia) that enable efficient record capture and editing. The multimedia module is particularly useful as it serves as a repository for images, video, audio, word processing documents, spreadsheets, presentations and executable files that can be linked to records in the catalogue (Fig. 2).

Another feature of $\mathrm{KE} \mathrm{EMu} \mathrm{is} \mathrm{the} \mathrm{mapping} \mathrm{module,}$ which allows users to generate distribution maps of particular pathogens (Fig. 3). Specimens of plant diseases collected on surveys are now routinely accompanied by precise locations, including latitude and longitude generated by a Geographical Positioning System. Surveys for plant pathogens provide early detection of exotic and emerging plant diseases. These distribution maps can be used to support area freedom requirements that manage quarantine risk by allowing the

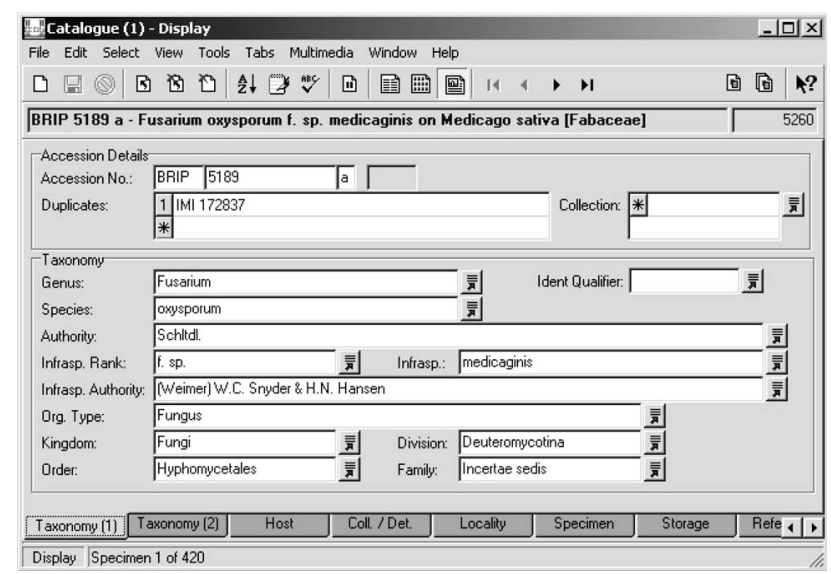

Fig. 1. Example of the taxonomy 1 display in the KE EMu database catalogue module.

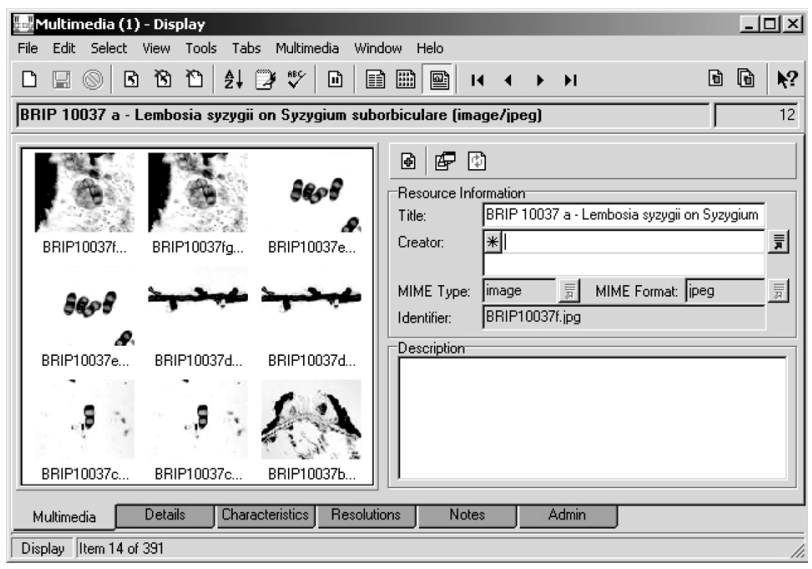

Fig. 2. Example of the multimedia display in the KE EMu database multimedia module.

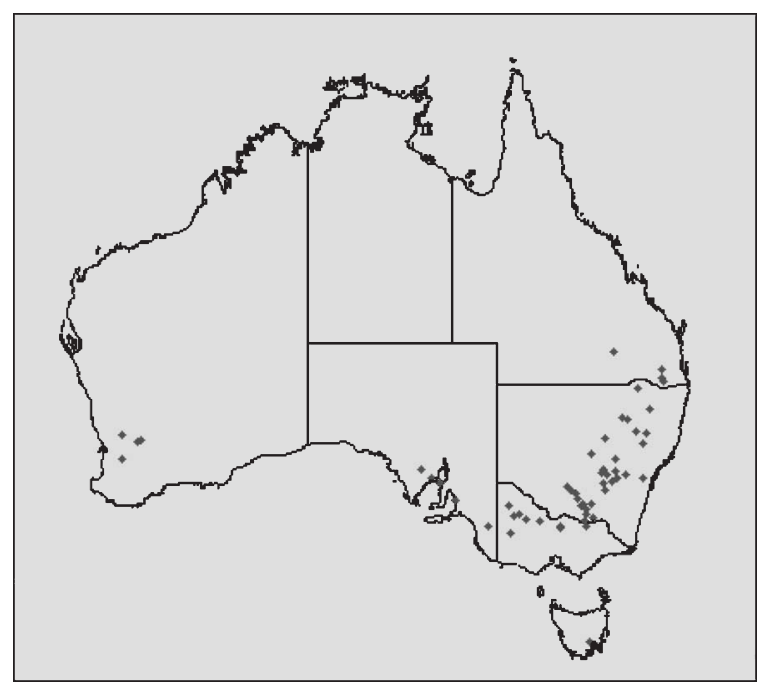

Fig. 3. A distribution map of Urocystis agropyri generated by APDD. 
exportation of agricultural commodities from areas that are free of particular plant pathogens.

$\mathrm{KE} \mathrm{EMu} \mathrm{has} \mathrm{enabled} \mathrm{better} \mathrm{management} \mathrm{of} \mathrm{the}$ plant disease collection and specimen records. This has been achieved through the generation of automated loan reminders (loans module), linking specimens to relevant publications (bibliography module), improved handling of collector, determiner and author information (parties module), using search and sorting functions that bring to light unusual records or errors in the database that require validation or correction (catalogue module), the rapid generation of pest lists (see below) and annotated checklists (Braun et al. 2005).

APDD provides data to the Australian Plant Pest Database (APPD), which is managed by Plant Health Australia using funding from a Commonwealth Budget Initiative. CSIRO Division of Mathematical and Information Sciences developed APPD's gateway and broker software, which facilitates access to many distributed database systems via the Internet. The novel database software interrogates specimen-based pest and disease information held in a range of databases maintained by state, territory and Australian Government agencies. Only two databases, APDD and the catalogue of the Western Australian Department of Agriculture Plant Pathology Collection, contribute records of plant pathogens to APPD. The web address for APPD is www.planthealthaustralia.com.au/APPD (verified 31 January 2006).

APDD and APPD are examples of the growing number of online biological portals that provide access to specimen databases. From a world perspective, portals such as the Global Biodiversity Information Facility (GBIF) aim to make the world's biodiversity data openly and universally available via the Internet as a way to assist the sustainable use of biodiversity for future generations. Presently, APDD and APPD do not provide data to GBIF and access to both APDD and APPD is currently password protected and available to registered users only.

The value of specimen-based databases of plant pathogens from the perspective of Australia's agricultural industries is that it allows the development of specimen-based pest lists that are critical for resolving quarantine issues related to market access and agricultural trade. The completion of the Uruguay Round of trade negotiations under the General Agreement on Tariffs and Trade (GATT) and the establishment of the World Trade Organisation (WTO) in 1995 has significant implications for plant health and crop protection (www.wto.org, verified 31 January 2006). The WTO Agreement on Sanitary and Phytosanitary Measures (SPS) sets conditions, based on scientific principles and risk assessment, to protect agricultural industries from exotic pests (includes plant pathogens), yet at the same time facilitate trade in agricultural commodities. Member countries are required to maintain verified lists of pest and disease records. These records are used as a basis for pest risk analysis in bilateral trade negotiations. In Australia, these records can be accessed rapidly via APDD and APPD. Furthermore, these records are verifiable as APDD and APPD contain only specimen-based records.

Prior to the launch of APPD and APDD, the compilation of pest lists was time consuming as it relied largely on the availability of a few herbarium curators. There were published lists of plant disease for several States, namely Queensland (Simmonds 1966), Victoria (Chambers 1982; Washington and Nancarrow 1983; Woodcock and Clarke 1983; Cunnington 2003), Tasmania (Sampson and Walker 1982), South Australia (Cook and Dubé 1989), Western Australia (Shivas 1989) and Northern Territory (Pitkethley 1970), but these records were not always specimen-based and were always outdated. This meant that the compilation of pest lists for pest risk analyses could take months or years to compile, which delayed agricultural trade.

\section{Future}

Through the Internet, the whole scientific community can share information about plant pathogens. Photographic images of plant disease symptoms as well as photomicrographic images of pathogens transmitted over the Internet are a powerful tool in research, training, extension and diagnostics. Digitally assisted diagnosis (Holmes et al. 2000) has the potential to facilitate accurate plant disease diagnosis in contrast to the unfulfilled expectation that advanced molecular technologies such as real-time PCR would become routine in diagnosis (Schaad et al. 2003). Some of the benefits of digitally assisted diagnosis are that it is well suited to diseases that produce characteristic symptoms, specimens that do not travel well, large specimens and specimens under quarantine control.

Various models have been proposed for the structure of a database that cross-links genotypic and phenotypic information about plant pathogens (Kang et al. 2002). In Australia, we envisage that the specimen-based KE EMu database system has the potential to form the basis of a virtual plant disease herbarium similar to Australia's Virtual Herbarium (AVH), which is an online botanical information resource of six million specimen records, enhanced by images, descriptive text and identification tools (www.chah.gov.au/avh, verified 31 January 2006). The database could be linked to molecular sequence data or interactive computer guides. For example, BRIP staff are developing a Lucid key to the smut fungi (Ustilaginomycetes) of Australia (Fig. 4). Lucid is an interactive multi-access key developed by the Centre for Biological Information Technology, The University of Queensland. The key can be distributed via $\mathrm{CD}$ or made available on the Internet. A wide range of end-users, including educators in secondary schools and universities, taxonomists, biodiversity scientists and conservation managers, are using Lucid keys. A list of published Lucid keys can be found at www.lucidcentral.org (verified 31 January 2006). 


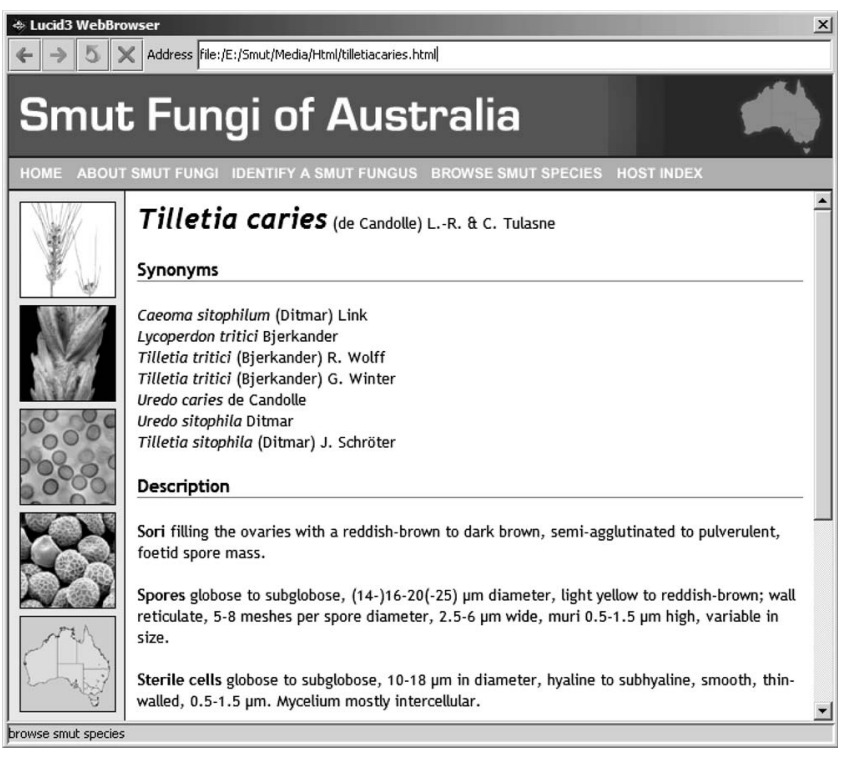

Fig. 4. Screen capture of the draft Lucid guide for Australian smut fungi.

The advantage of Lucid keys over traditional dichotomous keys is the ability to select any character state as a starting point rather than working through a pre-defined series of numbered questions. This approach avoids the problem of the unanswerable couplet that is often encountered when working with dichotomous keys. Lucid allows each of the taxa and their character states to be supported with text, images, video and sound.

Accurate diagnosis depends on access to authentically named reference specimens. It is the specimens in the herbarium collections that allow the validation of the names of pathogens in the databases. With the development of increasingly sophisticated molecular techniques for plant pathogen diagnosis, the collections have become valuable as a source of DNA as accurately identified specimens are fundamental to any molecular and phylogenetic analysis. For example, diagnostic identification using molecular techniques on a dried herbarium specimen in DAR invalidated a single entry of Phytophthora fragariae var. fragariae and is now being used to change the quarantine status for this species (André Drenth, pers. comm.).

Despite their demonstrated importance, collections of plant pathogens are, in most countries including Australia, seriously understaffed and underresourced. For example, in Australia there are only three full-time taxonomic mycologists who have to work with an estimated 250000 species of fungi (May 1995). Any institution that maintains a collection of value to the scientific community has an ethical and often a legal responsibility to ensure that the collection in its care is protected, secured, cared for and preserved. It is essential that the institution provide the resources, including qualified technical and professional staff, money, appropriate space and equipment needed for the long-term preservation and documentation of the collection in its care. The future security and health of Australia's agricultural industries, and the environment, depend on these collections of plant pathogens and their associated databases.

\section{References}

Braun U, Cunnington JH, Priest MJ, Shivas RG, Schubert K (2005) Annotated check-list of Ramularia species in Australia. Australasian Plant Pathology 34, 509-515. doi: 10.1071/AP05055

Chambers SC (1982) Lists of diseases recorded on ornamentals, native plants and weeds in Victoria, before 30 June, 1980. Technical Report Series No. 61. Department of Agriculture, Victoria.

Cook RP, Dubé AJ (1989) 'Host-pathogen index of plant diseases in South Australia.' (South Australian Department of Agriculture)

Cunnington JH (2003) 'Pathogenic fungi on introduced plants in Victoria. A host list and literature guide for their identification.' (Victorian Department of Primary Industries)

Holmes GJ, Brown EA, Ruhl G (2000) What's a picture worth? The use of modern telecommunications in diagnosing plant diseases. Plant Disease 84, 1256-1265.

Holmgren PK, Holmgren NH, Barnett LC (1990) 'Index Herbariorum. Regnum Vegetabile Vol. 120.' 8th edn. (New York Botanical Garden: Bronx, NY)

Kang S, Ayers JE, DeWolf ED, Geiser DM, Kuldau G, et al. (2002) The internet-based fungal pathogen database: a proposed model. Phytopathology 92, 232-236.

May TW (1995) Fungi. In 'Overview of the Conservation of Nonmarine Non-vascular Plants in Australia'. Draft report prepared for Endangered Species Unit, Australian Nature Conservation Agency.

May TW (1997) Fungi. In 'A Conservation Overview of Australian Non-marine Lichens, Bryophytes, Algae and Fungi'. (Eds GAM Scott, TJ Entwisle, TW May, GN Stevens) Available at www.deh.gov.au/biodiversity/threatened/action/cryptogams/10.html (verified 31 January 2006)

May TW, Pascoe IG (1996) History of the taxonomic study of Australian fungi. In 'Fungi of Australia. Vol. 1A'. pp. 171-206. (Australian Biological Resources Study: Canberra)

Pitkethley RN (1970) A preliminary list of plant diseases in the Northern Territory. Technical Bulletin No. 2. Primary Industries Branch, Northern Territory.

Sampson PJ, Walker J (1982) 'An annotated list of plant diseases in Tasmania.' (Department of Agriculture: Tasmania)

Schaad NW, Frederick RD, Shaw J, Schneider WL, Hickson R, et al. (2003) Advances in molecular-based diagnostics in meeting crop biosecurity and phytosanitary issues. Annual Review of Phytopathology 41, 305-324. doi: 10.1146/annurev. phyto.41.052002.095435

Shivas RG (1989) Fungal and bacterial diseases of plants in Western Australia. Journal of the Royal Society of Western Australia 72, $1-62$.

Simmonds JH (1966) 'Host index of plant diseases in Queensland.' (Queensland Department of Primary Industries)

Washington WS, Nancarrow RJ (1983) Lists of diseases recorded on fruit and vegetable crops in Victoria before 30 June, 1980. Technical Report Series No. 66. Department of Agriculture, Victoria.

Woodcock T, Clarke RG (1983) List of diseases recorded on field crops and pastures in Victoria before 30 June, 1980. Technical Report Series No. 65. Department of Agriculture, Victoria.

Received 14 January 2005, accepted 30 April 2005 